\title{
Project engages culturally diverse parents in Proposition 10 decisions
}

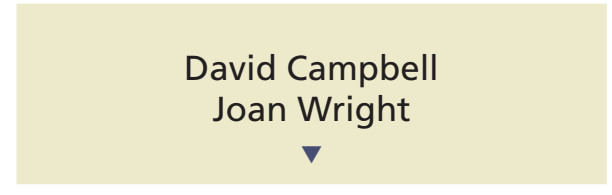

California's Proposition 10, a tax on tobacco products passed in 1998, provides counties with funds to improve the health, education and school readiness of children up to age 5. A foundation-sponsored Civic Engagement Project (CEP) seeks to promote inclusive participation in Proposition 10 decisions by engaging a broad spectrum of parents and other community members. Based on our systematic evaluation of the CEP's initial years of work, we describe six different civic engagement tools adopted by counties, strengths and weaknesses of each, and what we learned about the conditions under which they are most effective. The results illuminate a key public challenge - how to welcome culturally and linguistically diverse Californians as active and valued participants in local civic processes while obtaining meaningful guidance for decision-making.

\footnotetext{
alifornia's increasing class disparities and cultural and linguistic diversity place new strains on public institutions (Baldassare 2000). The full spectrum of the state's citizens should be engaged in community governance processes so that new voices are heard and public services reflect the needs
}

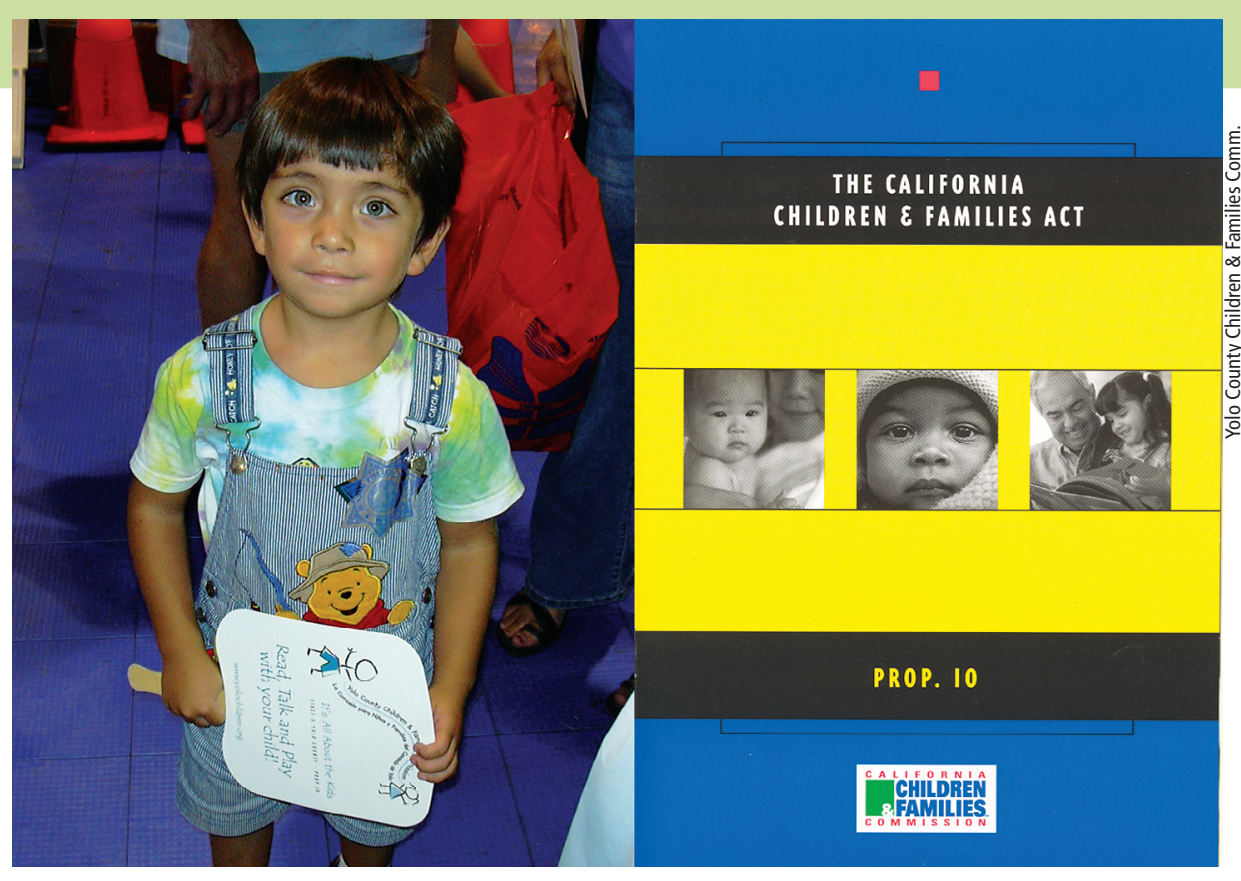

Proposition 10 taxes tobacco products to improve the health and school readiness of children 5 years old and under. County-based commissions decide how to distribute the funds. Left, a young boy visits a booth hosted by the Yolo County Children and Families Commission at the county fair; the commission's theme was "Read, Talk and Play With Your Child." Right, Proposition 10 guidelines and information.

and concerns of all groups. The political science and public administration literatures describe numerous tools for promoting public deliberation including issue forums (Button and Mattson 1999; Mathews 1994), deliberative polls (Fishkin 1991, 1995), citizen juries (Crosby et al. 1986; Kathlene 1991; Renn et al. 1993) and representative survey panels (Nagel 1992; Weeks 2000). However, these tools are frequently criticized as insufficiently inclusive, failing to reach beyond those who are already active and informed (Nagel 1992). Whether citizen participation is viewed primarily as an aid to improving public programs (Epstein et al. 2002) or as an ethical ideal (Denhardt and Vinzant 2000), addressing this shortcoming should be a high priority.

\section{Partnership for civic engagement}

In November 1998, California voters passed Proposition 10, a state ballot initiative that taxes tobacco products to create a multibillion-dollar revenue stream for improving the health and school readiness of children up to age five. Commissioners in each of California's 58 counties decide how local funds (apportioned by birth rate) are spent and how the state-required public input is obtained and incorporated. Beginning in 1999, five California foundations interested in civil investing and eight county-based Children and Families Commissions teamed up to form the Civic Engagement Project for Children and Families (CEP). The CEP augmented commission resources so that a broader spectrum of the public could be involved in local Proposition 10 planning. The local participants - known variously as "Proposition 10 Commissions," "Children and Families Commissions," or, more recently, "First Five Commissions" - are in Contra Costa, Monterey, San Diego, San Francisco, San Mateo, Santa Clara, Santa Cruz and Yolo counties.

Recognizing that civic engagement must be tailored to local conditions, CEP staff did not dictate a single ap- 
TABLE 2. Economic and demographic variation in CEP counties

\begin{tabular}{|c|c|c|c|c|c|c|c|c|c|}
\hline County & Population & $\begin{array}{c}\text { Prop 10 } \\
\text { funds } \\
1999-00\end{array}$ & $\begin{array}{l}\text { Non-English- } \\
\text { speaking } \\
\text { groups* }\end{array}$ & Whitet & Latino & Asian & $\begin{array}{c}\text { African } \\
\text { American }\end{array}$ & $\begin{array}{c}\text { Per } \\
\text { capita } \\
\text { income } \neq\end{array}$ & $\begin{array}{c}\text { Child } \\
\text { poverty } \\
\text { rate§ }\end{array}$ \\
\hline & & $\$$ millions & $\ldots \ldots \ldots$ & $\cdots$ & $\%$. & $\ldots$ & $\ldots \ldots$ & & $\%$ \\
\hline Contra Costa & 932,000 & 12.8 & 12 & 66 & 13 & 11 & 9 & 5 & 14 \\
\hline Monterey & 390,900 & 7.0 & 3 & 47 & 38 & 8 & 6 & 14 & 24 \\
\hline San Diego & $2,833,500$ & 45.0 & 4 & 61 & 24 & 8 & 6 & 17 & 20 \\
\hline San Francisco & 797,200 & 8.5 & 9 & 41 & 16 & 33 & 10 & 2 & 21 \\
\hline San Mateo & 727,300 & 10.5 & 9 & 54 & 21 & 20 & 5 & 3 & 9 \\
\hline Santa Clara & $1,717,600$ & 27.5 & 10 & 51 & 23 & 22 & 4 & 4 & 14 \\
\hline Santa Cruz & 253,400 & 3.7 & 1 & 71 & 23 & 4 & 1 & 9 & 19 \\
\hline Yolo & 158,900 & 2.2 & 11 & 86 & 22 & 9 & 20 & 17 & 22 \\
\hline Statewide & $34,036,000$ & 546.0 & 8 & 52 & 29 & 11 & 7 & - & 23 \\
\hline
\end{tabular}

* Number of languages other than English spoken by $1 \%$ or more of the English learners in the county's public schools.

† Percentage of total county population in each category.

₹ County ranking of all 58 California counties by per capita income.

$\S$ Estimated percentages of people under 18 in poverty in California.

Sources: California Department of Finance 1999 (population); California Legislative Analyst Office 2002 (Proposition 10 funds); California Department of Education 2002 (languages spoken); California Department of Finance 1997 (racial/ethnic makeup); US Department of Commerce 1997 (per capita income); US Census Bureau 2001 (poverty rate).

cans, Asian-Pacific Islanders, parents of children with special needs, homeless families and incarcerated parents.

\section{Civic engagement tools}

The eight counties implemented a variety of civic engagement "tools" - coordinated activities designed to foster inclusive participation in the work of the commission (table 3 ). The following sections describe the six most significant tools, their strengths and weaknesses, and our working hy- potheses about the conditions needed for the tool to be most effective.

Advisory committees. Advisory committees are a familiar form of citizen participation, and under Proposition 10 guidelines each county must designate at least one such body. But because recognized expertise is often a qualification for selection, advisory committees typically attract those already engaged at the expense of lesser-heard voices. The CEP prompted experiments to move beyond this status quo, altering the nature, composition and functions of particular advisory groups.

For example, San Diego's commission created a technical and professional advisory committee whose 15 members represent well-known service providers to make formal recommendations to the commission. To ensure that this committee was informed by citizen voices, one meeting per quarter was rotated among different regions of the county and ended with an open community conversation designed to inform the committee of community concerns and increase awareness about

TABLE 3. Major civic engagement tools used by CEP counties

\begin{tabular}{|c|c|c|c|c|}
\hline Tool & Nature & Strength & Weakness & $\begin{array}{l}\text { Counties } \\
1999-2002\end{array}$ \\
\hline $\begin{array}{l}\text { Advisory } \\
\text { committees }\end{array}$ & $\begin{array}{l}\text { Provide advice to } \\
\text { commission }\end{array}$ & $\begin{array}{l}\text { Potential for } \\
\text { substantial influence } \\
\text { over decisions }\end{array}$ & $\begin{array}{l}\text { Typically engages } \\
\text { experts rather than } \\
\text { new parent voices }\end{array}$ & All \\
\hline $\begin{array}{l}\text { Outreach } \\
\text { workers }\end{array}$ & $\begin{array}{l}\text { Build relationships } \\
\text { with segments } \\
\text { of community }\end{array}$ & $\begin{array}{l}\text { Often effective at } \\
\text { overcoming language } \\
\text { and cultural barriers }\end{array}$ & $\begin{array}{l}\text { Community connection } \\
\text { can come at expense } \\
\text { of influence with } \\
\text { decision-makers }\end{array}$ & $\begin{array}{l}\text { Contra Costa } \\
\text { Santa Cruz } \\
\text { Santa Clara } \\
\text { Yolo } \\
\end{array}$ \\
\hline $\begin{array}{l}\text { Community } \\
\text { conversations }\end{array}$ & $\begin{array}{l}\text { Facilitated } \\
\text { public discussions } \\
\text { on community } \\
\text { issues }\end{array}$ & $\begin{array}{l}\text { Nonthreatening space } \\
\text { for hearing parents' } \\
\text { concerns, sharing } \\
\text { information, } \\
\text { building relationships }\end{array}$ & $\begin{array}{l}\text { Nonthreatening } \\
\text { meetings can } \\
\text { preclude substantive } \\
\text { policy discussions }\end{array}$ & All \\
\hline $\begin{array}{l}\text { Community } \\
\text { capacity- } \\
\text { building }\end{array}$ & $\begin{array}{l}\text { Develop local } \\
\text { leaders and } \\
\text { orgs. to help } \\
\text { achieve outcomes }\end{array}$ & $\begin{array}{l}\text { Intensive focus on few } \\
\text { leaders/organizations } \\
\text { can have snowball } \\
\text { effect on others }\end{array}$ & $\begin{array}{l}\text { Directly engages } \\
\text { small no. individuals } \\
\text { with few short- } \\
\text { term payoffs }\end{array}$ & $\begin{array}{l}\text { San Mateo } \\
\text { San Diego }\end{array}$ \\
\hline Minigrants & $\begin{array}{l}\text { Provide small grants } \\
\text { to nontraditional } \\
\text { recipients such as } \\
\text { parent groups, } \\
\text { neighborhood orgs. }\end{array}$ & $\begin{array}{l}\text { Parents and community } \\
\text { groups can complement } \\
\text { approaches of existing } \\
\text { agencies or pursue } \\
\text { innovative approaches }\end{array}$ & $\begin{array}{l}\text { Difficult to } \\
\text { implement due to } \\
\text { contracting and } \\
\text { liability rules, } \\
\text { red tape }\end{array}$ & $\begin{array}{l}\text { San Francisco } \\
\text { Santa Cruz }\end{array}$ \\
\hline $\begin{array}{l}\text { Program } \\
\text { design } \\
\text { workgroups }\end{array}$ & $\begin{array}{l}\text { Involve citizens } \\
\text { directly in design } \\
\text { of commission } \\
\text { programs }\end{array}$ & $\begin{array}{l}\text { Highly deliberative, } \\
\text { gives parents power } \\
\text { over major commission } \\
\text { expenditures }\end{array}$ & $\begin{array}{l}\text { High demands on staff } \\
\text { to recruit and train } \\
\text { parent participants } \\
\text { within bureaucracy }\end{array}$ & Santa Clara \\
\hline
\end{tabular}

Proposition 10. The commission also developed a separate layer of advisory structures called leadership teams to solicit advice on key commission initiatives. These teams elicited greater involvement of parents, and operated less formally since they reported to the executive director and not the commission, avoiding constraints imposed under the Brown Act (California's open meeting law).

Across the CEP counties, the more formal the advisory structure, the more power it tended to have, and the less likely it was to invite the regular participation of parents and community members. Conversely, less formal advisory structures were more likely to provide a welcoming setting for diverse participants, but tended to 
have less direct influence on commission decisions.

Our work identified the following working hypotheses regarding the conditions required for advisory committees to promote inclusive citizen participation:

- The commissioners are willing to entertain advice and/or to delegate part of their decision-making power to an advisory committee.

- There are clear agreements as to the committee's function, membership and role, such as whether it can make formal recommendations to the commission.

- Interests and experiences of a broad array of providers and community members are represented, giving the committee public legitimacy.

- Persons selected understand the content and process issues sufficiently to engage in informed deliberation.

- A safe and welcoming environment is created for discussion and continued learning, so that newcomers are not intimidated.

Outreach workers. Typically, commissions hired outreach workers with some previous history of community involvement to build relationships and connections with particular segments of the community - ethnic, class, neighborhood or special interest. For example, eight outreach workers in Santa Cruz, most bilingual Spanish-speakers, conducted intercept interviews at locations like migrant housing units, preschools, shopping malls and grocery stores. Contra Costa deployed a Spanish speaker to work in the heavily Latino east county area and a popular pastor to work in predominantly black Richmond. Santa Clara hired and trained 15 outreach specialists to target different ethnic groups and community sectors, such as the faith community and gay or lesbian parents.

In general, outreach workers were effective at overcoming language and cultural barriers and promoting more inclusive participation. On the other hand, we heard frequent mentions of a perceived disconnect between outreach work and the actual deliberations of the commissions. Local civic engagement staff often described themselves as caught between two different worlds,

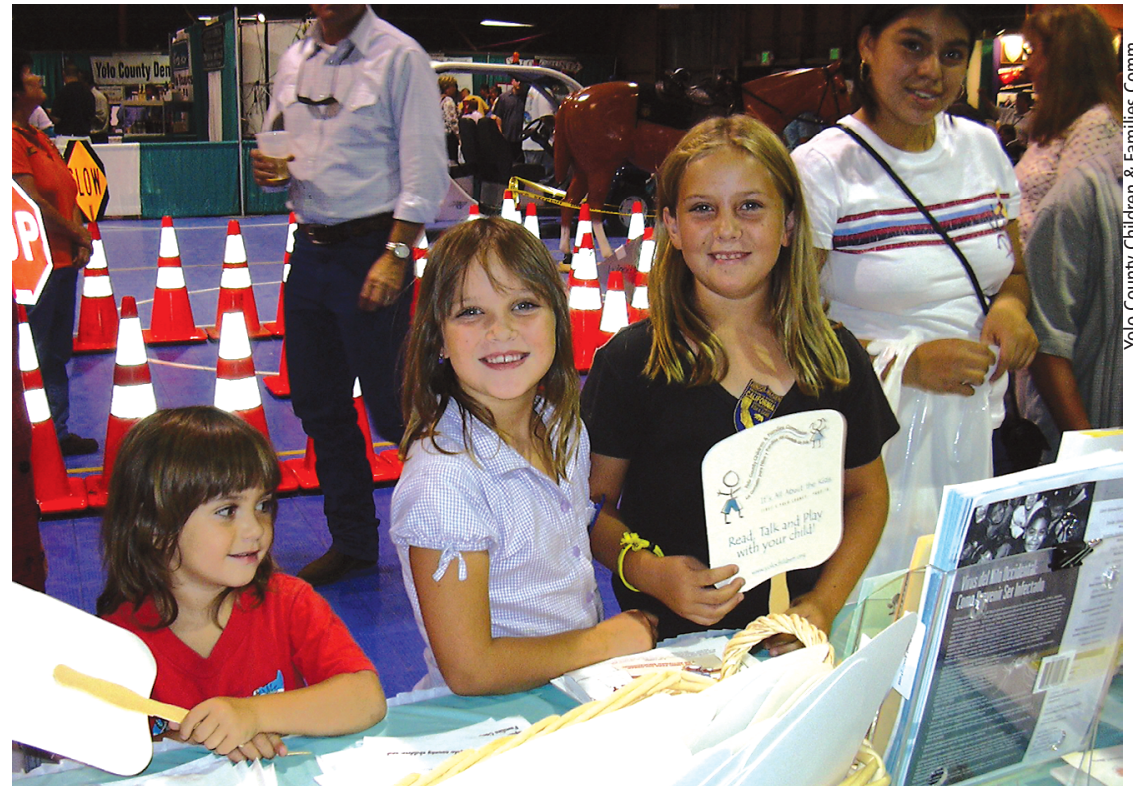

A group of foundations funded a civic engagement project to promote diverse participation in decision-making regarding how Proposition 10 funds are spent. Children visit the Yolo County commission's fair booth.

one heavily bureaucratic and formal and the other idiosyncratic and dependent on trusting personal relationships.

The CEP experience suggests several conditions required to effectively deploy outreach workers as a civic engagement tool:

- The commission can identify the community segments in need of an outreach worker, and commit sufficient funds to hire qualified individuals.

- Staff and outreach workers combine community respect and local knowledge with an understanding of the commission and its processes, and credibility with commissioners.

- Staff training and supervision are provided.

- Criteria are developed for determining the success of outreach worker efforts.

Community conversations. At the urging of CEP project staff, all counties experimented with some form of community conversation. This tool consists of episodic meetings designed to include a diverse set of parents and community members. Community conversations are primarily intended as an accessible entry point into the work of the commissions, rather than a vehicle for direct input into decisions. For example, Contra Costa's commission convened a series of regional community conversations centered on the question, "How can we make Contra
Costa a better place for families with young children?" The meetings were intended to provide commissioners with new program ideas and to give community participants the opportunity to learn about Proposition 10, apply for commission funds, become involved with commission committees or become advocates for children. Two meetings (1 week apart) were held in each of the four county regions. Commission staff arranged child care and dinner and simultaneous English-Spanish translation where necessary. Outreach techniques included invitations (in English and Spanish) on the commission's mailing list; articles in local mothers' club newsletters; recruitment by community agencies and child-care centers; advertising in the local newspaper; and existing e-mail networks.

Hiring outreach workers with credibility in their communities appears to have contributed to attendance (40 to 60 diverse participants per meeting), as did the incentive of a $\$ 40$ gift certificate for attending both sessions. The use of the fiscal incentive was unique to Contra Costa County; therefore, we have no comparative basis for ascertaining how large a role it played in facilitating the involvement of lower-income parents.

The meetings we observed demonstrated the value of encouraging broad participation and listening to everyone with respect. Participants said the meetings made them aware of previously unknown services and of the concerns 
of parents in social circumstances different from their own. On the other hand, these cross-class encounters were at times jarring, as when two women we interviewed from wealthy neighborhoods indicated that they felt out of place at a meeting dominated by concerns over unsafe parks and drug dealing.

Staff using community conversations faced one recurring choice: whether to convene groups that were homogeneous or heterogeneous. Some opted for working primarily with groups that shared a history of working together, or some bond of ethnicity, culture or language. Others, like Contra Costa, attempted to gather diverse publics for conversation. While the latter seems preferable from the standpoint of deliberative ideals, most staff actually preferred the former, since it tended to be more appealing to parents unfamiliar with public meetings, especially among immigrant populations.

The features of community conversations that are critical to supporting inclusive and deliberative participation include:

- Staff ensures that the issue-related conversations are framed, convened and facilitated appropriately, and that food, child care and translations are provided as needed.

- Follow-up opportunities allow interested individuals to become involved.

- Comments, concerns and information are accurately and sensitively recorded and conveyed to participants and decision-makers.

- The commission does not ignore the feedback, but carefully considers it.

- Citizen participants are kept informed about what is happening to the ideas they offered and any resulting commission decisions or tangible outcomes.

\section{Community capacity-building.}

This form of civic engagement seeks to develop local leaders and organizations whose assets help the commission achieve intended outcomes and whose approaches model promising practices of civic engagement. San Diego's commission contracted with the Consensus Organizing Institute (COI) of California State University, San Diego to develop
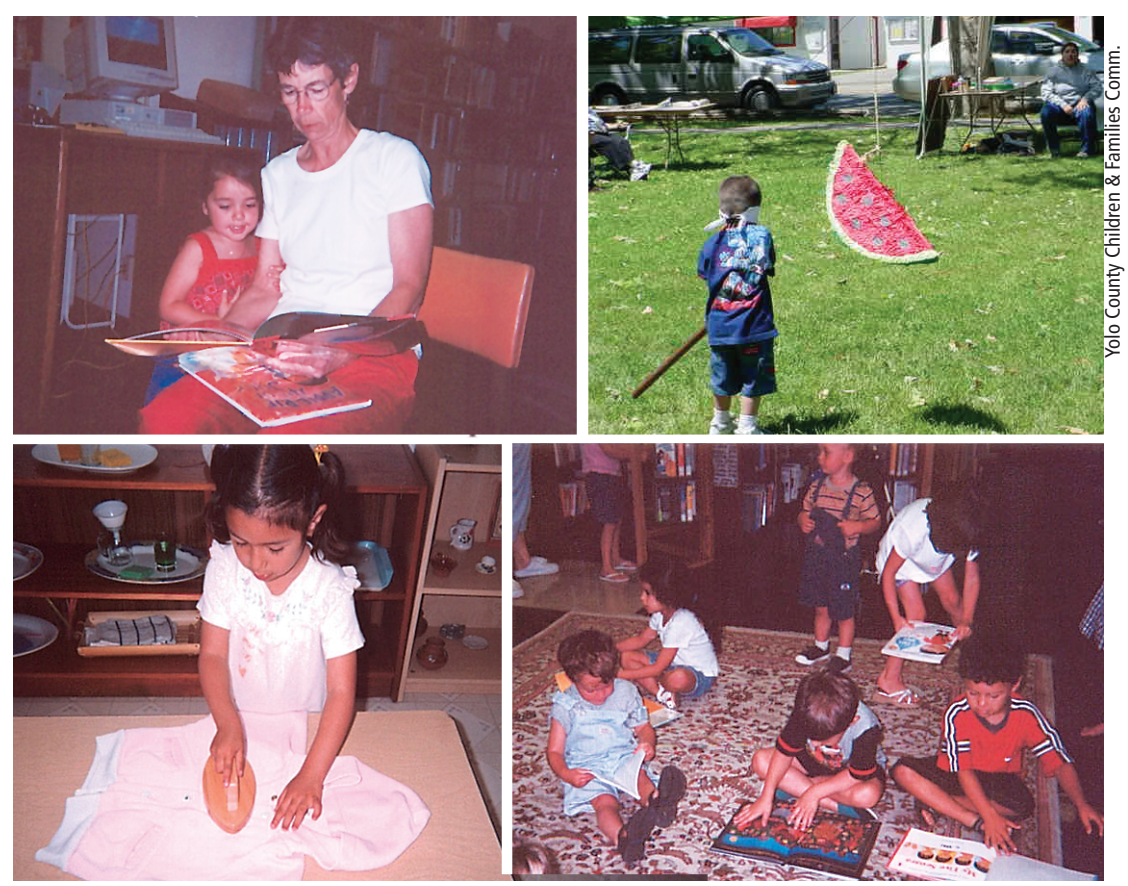

Young children benefit from programs that promote school readiness in a fun environment Proposition 10 encourages parents to be active and informed participants in deciding what types of programs their children need. Clockwise from upper left, at the Winters

library, a grandmother reads a book purchased with minigrant funds awarded to Friends of the Library; a boy hits a piñata at the Esparta Cultural Fair, also funded by the Yolo County commission; and preschool children read books in Spanish and practice "life skills."

community leadership in three pilot collaboratives. In each, a core group of six to 10 parents identified by the COI organizer met weekly and then reached out to involve other parents (such as by creating service directories and holding school-readiness forums). The COI approach emphasizes careful and patient nurture of self-selected parent leaders who are willing to invest time and energy. The theory is that intensive focus on a few citizen leaders will create a snowball effect that promotes more widespread participation.

San Mateo's commission conducted more than 91 public dialogues regarding early childhood issues in partnership with the Peninsula Conflict Resolution Center. Their purpose was not to influence commission decisions, but rather to develop individual leaders to advocate for young children. In engaging San Mateo's target audience - Latina women with little previous connection to public affairs - staff spent their time cultivating trust and personal relationships, one at a time. In their understanding, "a dialogue is an intense personal encounter with someone you trust," rather than a formal deliberation about public issues.

Here is a partial list of elements that go into designing an effective community capacity-building strategy:
- The commission partners with an existing community organization or uses its own staff.

- Whoever leads the capacity-building effort strikes a balance between being supportive and being directive.

- Parents and other community members identify roles they can play to make a difference.

- Parents and other participants learn by doing and gain skills, knowledge, experience and confidence.

- Recognition of community partners by the commission is frequent and perceived as genuine.

Minigrants. Minigrants are awards of $\$ 500$ to $\$ 10,000$ that go to nontraditional recipients, such as parent groups, small neighborhood organizations or home-based child-care providers. For example, Santa Cruz awarded 40 minigrants of up to $\$ 10,000$ to family childcare providers to purchase equipment and materials. Outreach workers helped publicize the grants and hosted workshops. Recipients were grateful to the commission for reaching out to people who had never previously received public funding.

The San Francisco commission's Parent ACTION (Achieving Change Together in Our Neighborhoods) grant program took the additional step of 
creating a parent selection board with the authority to recommend proposals. Also, the application process was simple and accessible with ample technical assistance (10 formal workshops plus individual assistance). As a result, the selection board, applicants and funded programs were widely perceived as representing the diversity of San Francisco's population in terms of race, ethnicity, neighborhoods and language spoken.

San Francisco commission staff discovered that genuine efforts to share power with citizens take more staff time and energy rather than less, and representatives of funded programs reported that procedures for getting funds from the city were cumbersome and challenging. Staff had to help project leaders adjust to the city grant process and vice versa, and spent considerable time negotiating contractual and reporting agreements.

The conditions required to implement minigrants as an effective citizen participation tool include:

- Staff has the ability to simplify the application process and help neophytes.

- Staff can convince bureaucrats to adapt their usual expectations regarding insurance, reporting and accountability to the realities of a small grants program.

- There is capacity to encourage applications in languages other than English.

- The commission staff can find a balance such that sufficient proposals are attracted, but not so many that the rejection rate creates bad will in the community.

Program design workgroups. The most ambitious civic engagement strategy we observed involved citizens directly in the design of commissionfunded initiatives and programs. The Santa Clara commission stipulated that major Proposition 10 funding would be directed by regional partnerships with at least $51 \%$ of their membership from parents and non-agency-affiliated community members rather than from provider groups. When this condition was met, the partnerships had autonomy to create a community-based plan that spent up to $\$ 2$ million over a 3-year period.
This form of citizen participation is highly deliberative and clearly linked to commission funding decisions. In Santa Clara's case, a representative group of local citizens - and the broader group of citizens from whom they gather input - was empowered to play a critical role in deciding how millions of dollars were spent. Program design workgroups are effective citizen participation tools when:

- The local political culture and commission support power-sharing with citizens, and back their commitment with significant funding.

- Staff can invest the extra time required to orchestrate meaningful involvement of community members in the complicated design process.

- Community members are sufficiently convinced that their voices will be heard so that they are willing to commit time and energy.

- Commission requests for revisions of design workgroup proposals are clearly explained with a chance for the group to defend its ideas.

- Participants are informed of the final product of their work, and recognized for their contributions.

\section{Engaging diverse parents}

The CEP successfully created rich laboratories for learning about civic engagement practices in culturally diverse settings. As of November 2003 the eight-county project was still under way, and it has begun to influence how other California counties are engaging new and often unheard voices in policy development. With respect to the three guiding principles, several significant CEP outcomes can be reported.

Inclusive participation. All the local commission partners conducted special outreach to diverse groups in many locations, made possible by CEP funds supporting culturally appropriate and bilingual outreach staff, translation services, child care and food. Low-income parents, teen parents, parents who are not English speakers, and others not usually involved participated in public meetings and planning processes.

Civic dialogue. The CEP was successful during its first and second years in promoting community meetings open and respectful of diverse publics. These

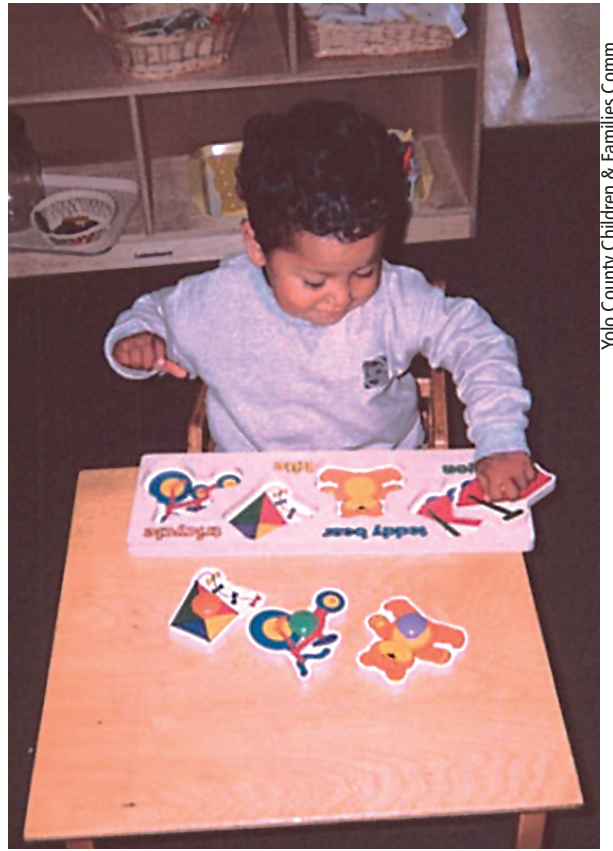

Some commissions fund minigrants to nontraditional recipients such as local parent groups and neighborhood organizations. In Yolo County, child-care providers received money to purchase age-appropriate developmental tools.

"exploratory dialogues" aired a range of perspectives and enhanced mutual understanding. It was more difficult to encourage framing practices that identified issues facing the commission for community discussion, or to implement "deliberative dialogues" where differences were probed and conflicts surfaced, or where there was a sustained effort to work through disagreements or tradeoffs to generate specific policy advice for commissioners.

Policy effectiveness. While it was not the major factor influencing commission decisions, civic engagement yielded some marginal impacts, such as agreements to fund minigrants, and increasing investments of the commission's own funds to support civic engagement staff. While funders and their local partners seemed satisfied with these limited policy results, we were reminded again of how difficult it is to build civic processes that are simultaneously inclusive, deliberative and politically effective. Seeing how far short of that ideal the wellfunded and often heroic CEP efforts fell adds credence to the conventional wisdom that it is difficult for Californians to establish common ground in the face of cultural diversity. Apparently, this is even true in policy arenas like children's issues in which there is widespread agreement about the need to act. 
We observed a tendency to treat diverse participation as an end in itself, rather than as an important step toward more effective community governance and better outcomes for children.

Our evaluation suggests three overarching lessons. First, the most important variable in a civic engagement process is the quality of the staff and leaders - their skill, commitment and persistence. All civic engagement work is labor intensive and nonroutine, and parents of young children are something of a moving target since their concerns change rapidly as children grow up. Civic engagement staff must blend local knowledge, clarity about purposes, sensitivity to diverse populations and the ability to both listen and lead. Critical factors include how many staff are employed full-time, how well they are paid and supported, how much experience they have and how well their style and backgrounds fit in the local context. Ideally, local staff should be conversant in multiple tools for civic engagement, learning to mix and match them depending on the desired outcomes.

Second, less obvious but extremely important, is the need to be clear about why inclusive and diverse participation is sought. We observed a tendency in these experiments to treat diverse participation as an end in itself, rather than as an important step toward more effective community governance and better outcomes for children. The potential purposes of inclusive participation include clarifying areas of conflict and consensus given group distinctions, promoting greater use of sometimes underutilized public services, increasing the legitimacy of the decisionmakers in all community segments and encouraging community "do it yourself" efforts.

Finally, to engage parents as citizens, their involvement can be viewed in a variety of guises, whether as rationally informed participants serving on committees and taking part in community discussions; as customers giving feedback on services received; or as citizen problem-solvers acting to improve the lives of young children. In pursuing strategies to enhance these types of in- volvement, we must never forget that all parents, regardless of their degree of civic engagement, are already playing a critical and ongoing role as the de facto "frontline service providers" most responsible for educating the state's future citizens.

Note: The full CEP evaluation report is at: www.ccp.ucdavis.edu. For more information about the CEP, go to: www.civicengagementproject.org.

\section{Campbell is Cooperative Extension} Specialist, Community Studies, and Director, California Communities Program, and J. Wright is Cooperative Extension Specialist, Emeritus, Department of Human and Community Development, UC Davis. The authors thank UC Cooperative Extension (UCCE) personnel who served as local observers on the evaluation team: Gloria Brown, County Director, San Francisco and San Mateo counties; Rebecca Carver, past 4-H Youth Development Advisor, Yolo County; Faye Lee, 4-H Youth Development Advisor and Home Economist, San Francisco and San Mateo counties; Fe Moncloa, 4-H Youth Development Advisor, Santa Clara County; Shelley Murdock, 4-H Youth Development Advisor, Contra Costa County; Estella West, Family and Consumer Sciences Advisor, Santa Clara County; Martha Weston, Food Stamp Nutrition Education Program Statewide Program Manager, Nutrition Department, UC Davis (formerly with UCCE San Diego). Other local observers were Yvonne Ricketts and Anne Sanchez in Monterey County, and Sue Pierce in Santa Cruz County. Cathy Lemp conducted interviews with public participants in English and Claudia Sandoval and Gloria Widener interviewed Spanish-speaking participants. Foundations sponsoring the CEP included the David and Lucile Packard Foundation, James Irvine Foundation, Miriam and Peter Haas Fund, Peninsula Community Foundation and Walter and Elise Haas Fund.

\section{References}

Baldassare M. 2000. California in the New Millennium: The Changing Social and Political Landscape. Berkeley, CA: UC Press.

Button M, Mattson K. 1999. Deliberative democracy in practice: Challenges and prospects for civic deliberation. Polity 31(4):60937.

California Department of Education. 2002. English-Learners in California Public Schools, by Language and Grade, 1999-00. Sacramento, CA.

California Department of Finance. 1997. Race/Ethnic Population Estimates: Components of Change for California Counties, April 1990-July 1997. Demographic Research Unit. Sacramento, CA.

California Department of Finance. 1999. County Population Estimates and Components of Change, 1998-99. Demographic Research Unit. Sacramento, CA.

California Legislative Analyst Office. 2002. County Allocations of Proposition 10 Revenues Based on LAO Estimated Revenues, 1999-00 Amounts. Sacramento, CA.

Crosby N, Kelley JM, Schaefer P. 1986. Citizen panels: A new approach to citizen participation. Public Admin Rev 46(2):170-8.

Denhardt R, Vinzant J. 2000. The new public service. Public Admin Rev 60(6):54959.

Epstein P, Wray L, Marshall M, Grifel S. 2002. Engaging citizens in results that matter: A model for effective 21st century governance. In: Newcomer K, Jennings E, Broom C, Lomax M (eds.). Meeting the Challenges of Performance-Oriented Government. American Society for Public Administration, Washington, DC. p 125-60.

Fishkin JS. 1991. Democracy and Deliberation: New Directions for Democratic Reform. New Haven, CT: Yale Univ Pr.

Fishkin JS. 1995. The Voice of the People: Public Opinion and Democracy. New Haven, CT: Yale Univ Pr.

Kathlene L. 1991. Enhancing citizen participation: Panel designs, perspectives and policy formation. J Policy Analysis Manage 10(1):46-63.

Mathews D. 1994. Politics for People: Finding a Responsible Public Voice. Urbana, IL: Univ III Pr.

Nagel JH. 1992. Combining deliberation and fair representation in community health decisions. Univ Penn Law Rev 140(5):1965-85.

Renn O, Webler T, Rakel H, et al. 1993.

Public participation in decision making: $A$ three-step procedure. Policy Sci 26:189-214.

US Census Bureau. 2001. Current Population Survey. Poverty rates for 1998, reported in March 1999. Washington, DC.

US Department of Commerce. 1997. Personal Income and Per Capita Personal Income by County, 1995-97. Bureau of Economic Analysis. Washington, DC.

Weeks EC. 2000. The practice of deliberative democracy: Results from four large-scale trials. Public Admin Rev 60(4):360-72. 